Uniwersytet im. Adama Mickiewicza w Poznaniu

\title{
Ewolucja samorządu terytorialnego w Polsce w latach $1989-1998$
}

Rok 1989 zapoczątKową w Polsce wiEle zMiAN. NAJistotniejszA L nich była niewątpliwie transformacja ustrojowa państwa. W grudniu 1989 r. zostały wprowadzone zmiany w konstytucji, które gwarantowały demokratyczny system rządów i prawa obywatelskie. Transformacja wiązała się z szeregiem przemian społecznych oraz nową polityką gospodarczą państwa. Była też początkiem odrodzenia samorządu terytorialnego w Polsce. Zasadniczym celem prezentowanej pracy jest przedstawienie procesu transformacji samorządu terytorialnego w Polsce po 1989 r. ze szczególnym uwzględnieniem lat 1990 - 1998. Uwagę skoncentrowano przede wszystkim na przemianach w obrębie instytucji administracji państwowej. Praca traktuje również o organizacji administracji terenowej w tym okresie, a także o kompetencjach, jakimi poszczególne organy dysponowały.

Na potrzeby prowadzonych badań sformułowano następującą hipotezę: odrodzenie się samorządu terytorialnego jako lokalnego podmiotu władzy publicznej w połączeniu ze zmianami polityczno-prawnymi, sprawiło iż współczesny samorząd terytorialny nie jest tym samym podmiotem działalności publicznej jakim był na początku transformacji.

W zamyśle praca stanowi nie tylko opis stanu prawnego we wskazanym okresie, ale przynosi także analizę poszczególnych zmian dotyczących podnoszonej kwestii. Ważne jest wyjaśnienie wpływów, jakie zmiany polityczne i prawne wywierały na kształtowanie się samorządu terytorialnego. Podczas badań zastosowano metody: analizy źródeł, historyczną oraz porównawczą. Analiza źródeł opierała się na całościowym zbadaniu zaklasyfikowanego materiału. Metodę historyczną wykorzystano podczas badania dokumentów świadczących o rozwoju samorządu terytorialnego. Charakter pracy sprawił, że zastosowano również metodę porównawczą, zastosowaną przy odniesieniu do funkcjonowania instytucji samorządowych oraz działań politycznych. 
W artykule zaprezentowano proces budowy aparatu administracji państwowej prowadzący do wytworzenia się systemu funkcjonowania samorządu terytorialnego w formie istniejącej w teraźniejszości. W artykule przedstawiono uwarunkowania historyczne dotyczące omawianego zagadnienia. Ukazane zostały procesy ewolucji systemu politycznego, mające istotny wpływ na formowanie się administracji państwowej oraz jej instytucji. Umożliwiło to rozpoznanie podłoża powstania samorządu terytorialnego w Polsce.

Przedstawione zostały również podstawowe zadania i funkcje samorządu terytorialnego oraz znaczenie regulacji prawnych w odniesieniu do kształtowania się samorządu terytorialnego w Polsce. Ukazany został także proces przemian na gruncie administracji samorządowej, a także przyczyny oraz stymulanty rozwoju samorządu terytorialnego w kraju. Rozpatrzono w nim także wpływ zmian politycznych na możliwe kierunki rozwoju w zakresie dotyczącym administracji publicznej.

Program przeobrażeń ustrojowych w 1989 r. zakładał odtworzenie zlikwidowanych po II wojnie światowej, struktur samorządu terytorialnego. Było to naturalną konsekwencją postulatów wysuwanych od wielu lat przez reprezentantów środowisk społecznych i politycznych. W trakcie funkcjonowania systemu władzy scentralizowanej, wprowadzającej do sfery ustrojowej aparat jednolitych organów władzy ustrojowej, program przeobrażeń doprowadził do nieprawidłowości systemu zarządzania całokształtem życia społecznego, politycznego i ekonomicznego. Nadmiernie rozbudowane mechanizmy blokujące działalność władz lokalnych oraz innych podmiotów, skutkowały nikłymi możliwościami podejmowania przez władze lokalne własnych działań, dążących do zaspakajania potrzeb lokalnych.

Władze polityczne dążyły do limitowania zakresu działań oddolnych oraz ograniczenia inicjatyw społecznych (Doganowski 2001, 66 - 69).

Problematykę samorządową podniesiono podczas obrad Okrągłego Stołu. W rozmowach między przedstawicielami strony solidarnościowo-opozycyjnej, powołanymi przez utworzony 18 grudnia 1988 r. Komitet Obywatelski przy Lechu Wałęsie, a reprezentantami rządu wypracowano wspólne stanowisko i podpisano 4 marca 1989 r. tzw. Protokół Końcowy, na mocy którego uzyskano porozumienie w takich kwestiach jak przyznanie gminom osobowości prawnej, przekazanie im części mienia państwowego, zapewnienia samodzielności finansowej przez ustanowienie źródeł dochodów stałych, potrzeby zapewnienia stałej ordynacji wyborczej, stworzenia możliwości zaskar- 
żenia przez samorząd terytorialny decyzji władz państwowych do Naczelnego Sądu Administracyjnego i sądów powszechnych (Słobodzian, 2005, 47 - 48).

Negocjacje przy Okrągłym Stole były początkiem nowego etapu odbudowy samorządu. Przygotowując się do uregulowania istoty samorządności przepisami prawnymi, w pierwszej kolejności dokonano zmian prawnoustrojowych.

29 grudnia 1989 r. sejm wprowadził około 80 zmian w Konstytucji z dnia 22 lipca 1952 r. Między innymi gwarantowano udział samorządu terytorialnego w sprawowaniu władzy, co pozwalało na przygotowanie projektów ustaw samorządowych, które zostały przyjęte przez senat 18 stycznia 1990 r. W dniu 8 marca 1990 r. przyjęto nowelizację Konstytucji, w której zawarte było stwierdzenie, iż „Rzeczpospolita Polska gwarantuje udział samorządu terytorialnego w sprawowaniu władzy oraz uzupełniając ją nowym rozdziałem poświęconym samorządowi” (Ustawa z dnia 8 marca 1990 r. o zmianie Konstytucji Rzeczypospolitej Polskiej, poz. 94).

Istotne znaczenie dla rozpoczęcia funkcjonowania samorządu miały ustawy z dnia 8 marca 1990 r. o samorządzie terytorialnym i ordynacja wyborcza do rad gmin. Pierwsza z nich, ustaliła podstawy samorządu gminnego, druga, pozwoliła na przygotowanie i przeprowadzenie wyborów do nowo kształtujących się rad gminnych. W kolejnych dwóch miesiącach zostały uchwalone następne ustawy z tak zwanego pakietu samorządowego. Były to:

- ustawa z dnia 22 marca 1990 r. o terenowych organach rządowej administracji ogólnej (Dz. U. 1990, nr 21, poz. 123);

- ustawa z dnia 22 marca 1990 r. o pracownikach samorządowych (Dz. U. 1990, nr90, poz. 124);

- ustawa z dnia 10 maja $1990 \mathrm{r}$. wprowadziła nowe przepisy o samorządzie terytorialnym i ustawę o pracownikach samorządowych (Dz. U. 1990, nr 32, poz. 191);

- ustawa z dnia 17 maja 1990 r. o podziale zadań i kompetencji określonych w ustawach szczególnych pomiędzy organami gminy a organami administracji rządowej oraz o zmianie niektórych ustaw ( Dz. U. 1990, nr 34, poz. 198);

- ustawa z dnia 24 maja 1990 r. o zmianie ustawy - kodeks postępowania administracyjnego (Dz. U. 1990, nr 34, poz. 201);

- ustawa z dnia 14 grudnia 1990 r. o dochodach gmin i zasadach ich subwencjonowania (Dz. U. 1990, nr 89, poz. 518) zastą- 
piona ustawą z dnia 10 grudnia 1993 r. o finansowaniu gmin (Dz. U. 1990, nr 129, poz. 600);

- ustawa z dnia 11 października 1991 r. o referendum gminnym (Dz. U. 1990. nr 110, poz. 473);

27 maja 1990 r. przeprowadzono wybory samorządowe, co zapoczątkowało przebudowę administracji państwowej - od tej pory samorząd stanowił element ustroju państwa.

Utworzenie gmin w 1990 r. jako podstawowych i jedynych jednostek samorządu terytorialnego było związane z podziałem kompetencji między administracją centralną a samorządową z odejściem od zasady jednolitej władzy państwowej (Doganowski, 2001, 67-78).

Postanowienia znowelizowanej Konstytucji zostały uchylone i zastąpione postanowieniami zawartymi w rozdziale V ustawy konstytucyjnej, tak zwanej Małej Konstytucji, z dnia 17 października 1992 r. o wzajemnych stosunkach między władzą ustawodawczą i wykonawczą Rzeczypospolitej Polskiej oraz o samorządzie terytorialnym (Słobodzian 2005, s. 50).

Istotna dla nowo utworzonych jednostek samorządu, jakimi były gminy, była ustawa z dnia 8 marca 1990 r. o samorządzie terytorialnym, która została wielokrotnie nowelizowana. Natomiast na podstawie ustawy o podziale kompetencji między organami administracji publicznej (Wytrążek 2009, s.145 - 146) wyodrębnione z administracji publicznej samorządy zaczęły samodzielnie kształtować swój ustrój. Na podstawie wymienionych wcześniej ustaw, samorząd zyskał osobowość prawną, nabywaną z mocy prawa, a ich samodzielność podlegała ochronie sądowej. Wprowadzono jednolity system organów władzy. Najważniejszym z nich uznana została rada gminna, której członkowie wybierani byli w wyborach równych, bezpośrednich, powszechnych, większościowych lub proporcjonalnych (Słobodzian, 2005, s. 52).

Na mocy nowelizacji ustawy z 1992 r. o zmianie ustawy o samorządzie terytorialnym, wprowadzono obowiązek powoływania komisji rewizyjnej. Ustawa określała zadania komisji oraz jej skład osobowy, a także tryb powoływania i odwoływania jej członków. Komisje były zobowiązane do składania sprawozdań ze swojej działalności oraz przedkładania planów pracy do zaaprobowania przez komisję.

Ustawa o samorządzie gminnym wprowadziła zasadę domniemania właściwości rady gminnej we wszystkich spawach publicznych o znaczeniu lokalnym, określała też radę jako organ o kompetencji generalnej. Rada otrzymała możliwość delegowania przysługujących jej 
kompetencji pomiędzy inne organy, ale jedynie w granicach określonych w ustawach.

W ustawie tej wymienione zostały tak zwane zadania własne gminy, które pozostawały do jej wyłącznej właściwości, oraz drugi rodzaj zadań, jakimi były tak zwane zadania zlecone, które przekazywane były do realizacji przez administrację rządową. Nadawane tylko w drodze ustawy i po zapewnieniu środków finansowych na ich realizację .

Kontrolę nad zadaniami sprawowała administracja rządowa, która sprowadzała się do kryterium legalności, celowości, rzetelności i gospodarności. Rolę organu wykonawczego gminy odgrywał zarząd złożony z 4 do 7 członków, wybierany na 4 letnią kadencję. Przewodniczącym zarządu, wybieranym przez głosowanie, mogła zostać osoba spoza grona radnych

Ustawa z dnia 8 marca 1990 r. ustanowiła instytucję referendum, będącą formą demokracji bezpośredniej. Na podstawie nowych przepisów członkowie wspólnoty mogli występować z inicjatywą przeprowadzenia referendum w sprawie odwołania gminy przed upływem jej kadencji, oraz w innych sprawach ważnych dla gminy (Ustawa z 11 października 1991 o referendum gminnym, nr 110, poz. 473).

Powstanie samorządu gminnego wiązało się z koniecznością utworzenia na szczeblu województwa organu wyższego nad samorządem gminnym, którym został sejmik samorządowy. W skład sejmiku wchodzili delegaci z poszczególnych gmin, stanowił on swoistą reprezentację gmin wobec administracji rządowej.

Ustawa o samorządzie terytorialnym porządkowała też kwestie finansów publicznych, na jej mocy gmina prowadziła własną gospodarkę finansową na podstawie budżetu gminy.

System finansowy gmin został określony ustawą z dnia 14 grudnia 1990 r., której kolejne nowelizacje rozbudowały strukturę systemu finansowego gminy (Ustawa z 11 października 1991 r. o referendum gminnym, nr 110, poz. 473).

Kolejną ustawę o finansowaniu gmin przyjęto 10 grudnia 1993 r. Ustawa ta uległa nowelizacji w 1995 r. w związku ze zmianami w systemie oświaty.

Na mocy tego aktu prawnego, środkami dofinansowania gmin, oprócz dochodów własnych i uzupełnienia w postaci udziałów w podatkach państwowych były subwencje ogólne, czyli bezzwrotne środki finansowe wykorzystywane zgodnie z własnymi potrzebami gminy, przyznawane przez ministra finansów po zasięgnięciu opinii ogólnopolskiej reprezentacji gmin. 
Organami nadzoru nad samorządem terytorialnym, z mocy ustawy o samorządzie tetytorialnym, był prezes rady ministrów, wojewoda, regionalna izba obrachunkowa oraz zarząd komisaryczny. Powołanie nadzoru było związane z brakiem skuteczności w wykonywaniu zadań publicznych przez organy administracji rządowej (Doganowski 2001, s.76-79) .

W celu kontrolowania gospodarki finansowej jednostek samorządu terytorialnego powołane zostały regionalne izby obrachunkowe. Utworzone zostały jako państwowe jednostki budżetowe nadzorowane przez prezesa rady ministrów, na podstawie kryterium legalności. Od 1994 r. uprawnienia kontrolne otrzymała także Najwyższa Izba Kontroli, upoważniona do przeprowadzania kontroli organów samorządu terytorialnego , komunalnych osób prawnych i innych jednostek organizacyjnych. (Nawrot, Pokładecki, 1999, s. 25-31).

W ramach reformy przyznano samorządowi prawo do podejmowania decyzji administracyjnych we własnym imieniu i ochrony samodzielności władz samorządowych. W tym celu utworzono samorządowe kolegia odwoławcze przy sejmikach samorządowych. W 1994 r. przyjęto ustawę o samorządowych kolegiach odwoławczych, regulującą wewnętrzną organizację, zakres uprawnień i tryb pracy .

Ustawa o samorządzie terytorialnym wprowadziła regulacje dotyczące formy współdziałania gminnego. Pojawiło się pojęcie związków międzygminnych, zróżnicowanych na związki komunalne i porozumienia komunalne, które zostały w celu zaspokajania potrzeb lokalnej ludności. Związki te tworzone były na zasadzie dobrowolności, a przynależność ich członków była nieobligatoryjna (Tarno 2004, s.91).

Reforma z 1990 r., mająca na celu wprowadzenie standardów demokratycznych, wprowadziła szereg zmian znoszących cechy charakterystyczne dla ówczesnego ustroju państwa, zniosła także monopol polityczny partii, a nowo powstałe władze gminne na jej podstawie otrzymały prawo pełnienia funkcji publicznych w imieniu własnym i na własną odpowiedzialność.

Odrzucając zasadę jednolitej władzy państwowej gminy przejęły sferę spraw publicznych, wyłączonych spod zwierzchnictwa rządu. Uzyskały także osobowość prawną, czyli prawo do posiadania i zarządzania własnym majątkiem. Uczynienie gmin podmiotem własności komunalnej, powiązane było z przeprowadzeniem operacji wydzielania z mienia Skarbu Państwa składników majątkowych, koniecznych do wykonywania tej funkcji publicznej. Zniesiono też zasadę finansów 
publicznych. Gminy wyposażono w odrębne budżety, zasilane w dużej części prze dochody własne oraz subwencje. Zniesiono też dotychczasową zasadę jednolitości administracji publicznej (Doganowski 2001, s. $67-74)$.

Przemiany ustrojowe w latach 1989-1990 stały się podwaliną do przebudowy polskiej administracji publicznej. Początkiem zmian była nowelizacja Konstytucji RP oraz ustawa z dnia 8 marca 1990 r. o samorządzie terytorialnym. Nowo powstałe gminy otrzymały atrybuty autonomii, osobowość prawną oraz mienie komunalne, własne źródła dochodów, ochronę sadową, możliwość reprezentacji ponadgminnej i tworzenia zrzeszeń i związków ponadgminnych. Jednak przyjęte rozwiązania prawne nie były w stanie zagwarantować rzeczywistej niezależności gmin od państwa.

Ukonstytuowanie się w 1990 r. nowego podziału administracyjnego kraju było sukcesem w kształtowaniu niedemokratycznego ustroju państwa, jednak proces ten wymagał kontynuacji. Dominującą cechą systemu administracji była silna centralizacja władzy i koncentracja kompetencji administracyjnych na szczeblu centralnym. Wprowadzenie zasad wolnego rynku spowodowało wzrost ponadwojewódzkich podziałów specjalnych, co znacznie utrudniało prowadzenie kompleksowej polityki państwowej w skali ogólnokrajowej i terytorialnej (Wykrętowicz, 2008 s. 59 - 63).

System administracji funkcjonował wówczas według zasad branżowo resortowych, które przeważały nad układem terytorialnym. Przewaga takiego systemu powodowała konieczność angażowania wyższych szczebli decyzyjnych, ponadto niewłaściwy podział żądań i kompetencji między samorządem terytorialnym i administracją rządową oraz między poszczególnymi poziomami władz negatywnie wpłynął na autorytet władzy publicznej w Polsce (Pająk, 2008 s. 67 - 71).

Dwustopniowy podział administracyjny z 1975 r., tworzący w miejsce powiatów 49 małych województw oraz gminy, zerwał historyczne ukształtowania funkcjonalno przestrzenne. Tak utworzone województwa nie były regionami w znaczeniu historycznym, geograficznym czy przestrzennym. Nie odpowiadały standardom europejskim pod względem powierzchni, zaludnienia i potencjału rozwojowego. Niewłaściwe wytyczenie granic województw spowodowało powstanie obszarów silnych i dobrze rozwiniętych oraz słabych, bez potencjału, nie posiadających możliwości rozwoju. Województwo, jako jednostka podziału administracyjnego, nie posiadały organów przedstawicielskich reprezentujących społeczność województw, ani mandatów do prowadzenia 
własnej polityki.Zróżnicowany potencjał ekonomiczny uzależniał dużą ich część od centrum, co wykluczało zasadę samodzielności i samorządności.

Taki podział administracyjny był dysfunkcyjny, zwłaszcza na szczeblu województw. Koniecznością stało się utworzenie szczebla pośredniego między gminą a województwem.

Najistotniejszym celem reformy istniejącego systemu podziału administracji państwowej stało się przede wszystkim usprawnienie funkcjonowania państwa. Zamierzano zwiększyć operatywność władzy wykonawczej, która polegać miała na wprowadzeniu silnej i sprawnej administracji rządowej zespolonej likwidując tym samym podział resortowo-branżowy.

Administracja ta funkcjonować miałaby na wszystkich szczeblach podziału administracyjnego. Odpowiedzialność za prawidłowe i skuteczne wykonywanie funkcji państwa ponoszona byłaby przez jednoosobowy organ administracji publicznej - wójta starostę, wojewodę. Dzięki dekoncentracji administracji i decentralizacji zadań publicznych rząd podejmował decyzje dotyczące strategii rozwoju państw zamiast zarządzać sprawami jednostkowymi.

Przyjęte założenia wzorowane były na państwach Europy Zachodniej o wielkości i liczbie ludności zbliżonej do Polski. Rozwiązania stosowane we Francji, Włoszech, Hiszpanii czy Niemczech mogły stanowić inspirację do tworzenia podobnych rozwiązań w Polsce.

Starano się uwzględnić interes narodowy Polski w kontekście przyszłego członkostwa w Unii Europejskiej, przystosowując organizację terytorialną kraju i struktur samorządowych do standardów UE. Polityka prounijna zakładała trójstopniowy samorząd terytorialny, w którym województwo miałoby charakter regionu, będącego podmiotem współpracy międzynarodowej. Kierowano się wytycznymi wynikającymi ze względów ekonomicznych. Przeprowadzone analizy wykazały, iż optymalnym byłoby utworzenie 100 - 111 powiatów, które tworzyłyby jednocześnie w Unii Europejskiej jednostki trzeciego stopnia, tzw. NUTS 3. Czynnik ten jednak nie miał pierwszorzędnego znaczenia. Tworząc drugi poziom samorządu lokalnego kierowano się takimi kryteriami jak: akceptacja społeczności lokalnych, uwarunkowania historyczno-kulturowe, potencjał instytucjonalny użyteczność publiczna i geograficzna. Ostatecznie kształt powiatów oparty został na wskazaniach zawartych w art. 15 Konstytucji, uszczegółowionych w trzy kryteria delimitacji, mianowicie więzów tożsamościowych i akceptacji proponowanego podziału przez społeczność lokalną, in- 
stytucjonalnej zdolności do wykonywania ponadgminnych zadań publicznych na rzecz miasta i okolicznych gmin, wielkości jednostki powiatowej (Gilowska, Gorzelak, Jałowiecki, Sobczak, 1998 s. 48 ).

Kolejnym planem było zdecentralizowanie systemu finansów publicznych, budżety wszystkich szczebli samorządu terytorialnego stanowiłyby $25 \%$ wydatków publicznych. Podstawową kwestią dla systemu finansowego samorządu terytorialnego miało być określenie struktury rzeczowej i wielkości zadań realizowanych przez daną jednostkę, gminę, powiat czy województwo. Budowanie nowego systemu finansowego miało się opierać na dotychczasowych doświadczeniach oraz teorii finansów publicznych, uwzględniając zasady adekwatności środków publicznych do kompetencji i zadań władz publicznych określonego szczebla, konieczność zbudowania precyzyjnego systemu zasilania finansowego oraz systemu alokacji publicznych środków pieniężnych.

Zadania własne samorządu powinny mieć pełne pokrycie w dochodach własnych, co pozwoliłoby na kształtowanie systemu własnych źródeł dochodu, których wysokość byłaby adekwatna do budżetu danej jednostki, oraz subwencjonowanie i dotowanie do określonych granic dopuszczalności zadłużenia jednostek samorządowych udzielania emisji oraz emisji obligacji (Pająk 2007, s. 49).

Innym celem reformy było przystosowanie organizacji terytorialnej kraju i struktur samorządu terytorialnego do standardów powszechnych w Unii Europejskiej, w celu umożliwienia wykorzystania instrumentów prawnych i ekonomicznych oferowanych przez Unię, służących rozwojowi regionalnemu i współpracy międzynarodowej.

Utworzenie regionów pozwoliłoby na nawiązanie współpracy z dekoncentrowanymi strukturami europejskimi oraz włączenie Polski w europejską politykę regionalną. Umożliwiłoby to pozyskanie dużych transferów finansowych w ramach wyrównywania dysproporcji regionalnych. Najodpowiedniejszym podziałem byłby ten zakładający powstanie 13 dużych województw, co umożliwiłoby podjęcie współpracy z regionami Francji, Niemiec, Włoch i Hiszpanii (Dolnicki, 2001 s. 72 - 75).

Podczas budowy nowych rozwiązań z zakresu samorządu terytorialnego w Polsce wykorzystano doświadczenie innych krajów Europy Zachodniej. Jednak ze względu na specyficzne uwarunkowania historyczne, społeczne oraz ekonomiczne naszego kraju nie było możliwości przeniesienia gotowego modelu z tych krajów, ich doświadczenia 
stanowiły tylko punkt odniesienia i porównania do opracowywanych w Polsce koncepcji.

Głównym założenie przy tworzeniu samorządu terytorialnego była zasada unitarnego charakteru państwa ( B. Dolnicki 201 s.72 - 79).

$\mathrm{Na}$ mocy ustawy z 1998 r. ustalono, że powiat jako jednostka samorządu terytorialnego zdolna do realizacji zadań publicznych o charakterze ponadgminnym spełniać musi co najmniej jedno z ustalonych kryteriów, obszar powiatu musi wynosić co najmniej 2 tys. km, w skład powiatu wchodzi co najmniej 5 gmin, liczba mieszkańców wynosi co najmniej 100 tys. W szczególnie uzasadnionych przypadkach można było utworzyć powiat mimo nie spełnienia wymienionych warunków. Dla miast tracących status miast wojewódzkich przygotowano program „Dialog i rozwój”, dążono do utrzymania tych miast jako atrakcyjnych miejsc do inwestycji (Doganowski, 2001 s. 78 - 84).

W trakcie prac nad nowym samorządem terytorialnym w Polsce najczęściej pojawiały się propozycje trójstopniowego podziału terytorialnego kraju. Poza nielicznymi projektami proponującymi podział dwustopniowy, traktowany jako wariant przejściowy, środowisko reformatorów opowiadało się za reaktywowaniem polskiej tradycji układu terytorialnego sprzed 1975 r. Podstawowym założeniem była likwidacja ośrodków władzy centralnej i zastąpienie jej regionami w miarę możliwości samodzielnymi. W miejsce zlikwidowanych centrów wojewódzkich powołano by powiaty.

Przyjęcie koncepcji dużych województw prowadziło do sporów o ich liczbę oraz umiejscowienie. Propozycje wahały się od 12 do 49 województw, oraz stworzenia 8 - 10 makroregionów wzorem państw europejskiej. Ten sam problem powstał podczas ustalania ilości powiatów pojawiały się różne propozycje, rozważano utrzymanie ilości powiatów zbliżonej do liczby rejonów administracji specjalnej, czyli około 300. Pojawiały się też propozycje ograniczenia ich liczby do 150 .

Ostateczny kształt mapy podziału terytorialnego państwa był wynikiem kompromisu politycznego między rządem a opozycją. Ocena wprowadzonego z dniem 1 stycznia 1999 r. zasadniczego podziału terytorialnego miała nastąpić nie później niż do dnia 31 grudnia 2000 r. Nieuwzględnione w trakcie przygotowania projektu ustawy wnioski społeczności lokalnych, co do kształtu terytorialnego państwa miały szanse być zrealizowane. W razie uzasadnionej konieczności przewidziano dokonanie korekty granic województw.

Zmiany organizacyjne wynikłe $\mathrm{z}$ reformy administracji miały na celu przede wszystkim ukształtowanie nowego podziału terytorial- 
nego państwa w ramach którego mogłyby być realizowane cele reformy dotyczącej m. in. zwiększenia skuteczności i efektywności działania urzędów administracji publicznej oraz zarządzania finansami publicznymi na poziomie lokalnym i ponadlokalnym.

Kierunek zmian musiał być zgodny z zasadami Konstytucji RP, z dnia 2 kwietnia 1997 r., która określała unitarny charakter państwa, jednak nie wyznaczała w sposób szczegółowy kształtu zasadniczego podziału terytorialnego państwa (Doganowski, 2001, s. 81 - 84). Ustalony w ramach reformy administracyjnej podział państwa obejmował ponadgminne struktury administracji publicznej, wyznaczając ich nowy kształt na poziomie lokalnym w formie powiatu oraz regionalnym w formie województwa. Kolejnym krokiem było wprowadzenie 1 stycznia 1999 r. trójstopniowego zasadniczego podziału terytorialnego państwa, poprzez stworzenie samorządu gminnego, powiatowego i wojewódzkiego.

Nowe jednostki samorządu terytorialnego przyjęto na mocy przepisów z dnia 24 lipca 1998 r. o wprowadzeniu zasadniczego trójstopniowego podziału terytorialnego państwa uzupełnionej rozporządzeniem Rady Ministrów z dnia 7 sierpnia 1998 r. w sprawie utworzenia powiatów, przy czym zasady nadania gminom miejskim praw powiatu zastały określone w ustawie z dnia 5 czerwca 1998 r. o samorządzie powiatowym (Obrębalski, 2001. s. 77).

Nowa mapa administracyjna składała się z 16 województw, 308 powiatów ziemskich, 65 miast na prawach powiatu, tzw. miast grodzkich.

Według zasadniczego trójstopniowego podziału terytorialnego państwa największą jego jednostką jest województwo. Stanowi ono jednostkę terytorialną szczebla regionalnego w Polsce. Pojęcie województwo zawiera w sobie określone terytorium i ogół mieszkańców stanowiących z mocy prawa regionalną wspólnotę samorządową.

W ramach zmian w podziale terytorialnym mogła być dokonywane korekty ich granic na stopniu lokalnym, czyli gminnym i powiatowym. Zmiana liczby województw, ich nazw, siedziby władz samorządowych lub rządowych mogły nastąpić w legislacji ustawowej. Jako reprezentanta terenowej administracji rządowej ustanowiono reprezentanta Rady Ministrów - wojewodę.

Zasada dualizmu władzy na obszarze województwa jest uwarunkowana rozwiązaniami konstytucyjnymi, a usankcjonowaniem stanu jest ustawa z dnia 5 czerwca 1998 r. o administracji rządowej, zespolonej i niezespolonej (Wytrążek, 2009 s. 64 - 69). 
Miejsce pośrednie pomiędzy województwem a gminą zajął powiat, powołany na mocy rozporządzenia Rady Ministrów z dnia 7 sierpnia 1998 r. w którym określono jego granice, wymieniając gminy wchodzące w jego skład. Powiaty miały stanowić pozaformalną realizacją istniejących na danych obszarach uwarunkowanych historycznie więzi społecznych, ekonomicznych i kulturowych, środek do wykształcenia ponadgminnych ośrodków świadczących wyspecjalizowane usługi na rzecz społeczności lokalnych.

Powiat, będący jednostką podziału administracyjnego, obejmował obszary graniczących ze sobą gmin, ale niektóre z miast zostały wyodrębnione i otrzymały status miasta na prawach powiatu. Było to wynikiem decyzji sejmu, który w ustawie o samorządzie postanowil, że oprócz powiatów ziemskich lub miejskich statut ten otrzymają miasta byłych siedzib województw oraz liczące powyżej 100 tys. mieszkańców. Ustawa z dnia 5 czerwca 1998 r. zezwoliła również Radzie Ministrów na nadanie praw powiatu innym miastom, nie spełniającym kryterium ludnościowego czy historycznego.

Na podstawie zgłoszonych wniosków przedstawicieli środowiska samorządowego i społeczności lokalnych Rada Ministrów, zgodnie z ustawą o wprowadzeniu zasadniczego trójstopniowego podziału terytorialnego państwa, oraz ustawy o samorządzie powiatowym utworzyła z dniem 1 stycznia 2002 r. dodatkowo 7 nowych powiatów (Rozporządzenie Rady Ministrów z dnia 31 maja 2001 r., poz. 631).

Najmniejsza z jednostek zasadniczego trójstopniowego podziału terytorialnego państwa czyli gmina, scharakteryzowana jest jako odpowiednie terytorium wraz z zamieszkującymi na nim mieszkańcami, którzy z mocy prawa stanowią wspólnotę samorządową.

Gminy dzielą się na gminy miejskie, gminy wiejskie oraz miejsko-wiejskie. Cechami decydującymi o charakterze gminy są takie parametry jak: układ przestrzenny, osadniczy, społeczność, czy infrastruktura techniczna. Cechą charakterystyczną polskich gmin jest połączenie w ich granicach obszarów miejskich i wiejskich.

Wszystkie zmiany dotyczące podziału terytorialnego na poziomie gminy, takie jak tworzenie, łączenie czy podział gmin oraz ustalanie ich granic następują w drodze rozporządzenia Rady Ministrów. Zmian dokonywać może Rada Ministrów z własnej inicjatywy, jak również na wniosek zainteresowanej strony, po uprzednim przeprowadzeniu konsultacji z mieszkańcami gminy. Podobna procedura jest wymagana przy nadawaniu gminie bądź miejscowości statusu miasta wraz z wyznaczeniem granic terytorialnych (Słobodzian, 2005, s. 116). 
W ramach każdej gminy mogą być powoływane jednostki pomocnicze, takie jak sołectwa, dzielnice, osiedla i inne, których zasady tworzenia i mechanizmy funkcjonowania zawarte są w statucie gminnym. Inicjatywa do powołania jednostki pomocniczej należy do rady gminy, która powinna po konsultacji z mieszkańcami stosowną uchwałą (B. Dolnicki, 2001, s. 77 - 81).

Zakończenie działalności przez struktury administracji publicznej w dotychczasowym kształcie nastąpiło 31 grudnia 1998 r. Wtedy też rozpoczęto realizacje reformy decentralizacji i dekoncentracji wprowadzając struktury powiatowe i samorząd województwa.

Przełom XX i XXI w. miał decydujący wpływ na obecną strukturę samorządu terytorialnego. Przywrócenie samorządu terytorialnego na szczeblu gmin, a następnie na szczeblu powiatu i województwa jest z perspektywy czasu przełomem, zwrotem w kierunku demokratycznego państwa prawnego.

Budowa państwa demokratycznego z gospodarką funkcjonującą w oparciu o prawa rynkowe, była jednym z celów przemian ustrojowosystemowych w latach 90 tych. Podstawą dokonywanych zmian było założenie że opoką ustroju demokratycznego są społeczności lokalne $\mathrm{i}$ ich prawo do uczestniczenia w kierowaniu sprawami publicznymi. W tym czasie koniecznością stała się przebudowa administracyjna państwa.

Reformy lat 90-tych postrzegane są zazwyczaj jako terytorialny podział władzy i przekazanie jej samorządowi. Zmiany wprowadzono powoli ze względu na brak spójnej strategii spowodowany problemami życia publicznego i transformacji gospodarczej.

W zaprezentowanym artykule przedstawiono genezę transformacji samorządu terytorialnego w latach 1990-1998, wraz z uwzględnieniem ówczesnej sytuacji politycznej i prawnej, co pozwoliło osiągnąć założony cel pracy, jakim było zweryfikowanie hipotezy badawczej. Zmiany w funkcjonowaniu i strukturze samorządu terytorialnego będące wynikiem reformy administracyjnej z 1998 r., nadały mu kształt odmienny od pierwotnych założeń.

W marcu 1990 roku Sejm kontraktowy uchwalił ustawę o samorządzie terytorialnym. Na jej podstawie wprowadzono w miejsce istniejących w PRL rad narodowych rady gmin o znacznie większych uprawnieniach. Kolejny etap reformy administracyjnej, który nastąpił osiem lat później, polegał na wprowadzeniu dwóch dodatkowych szczebli samorządu jakim były powiaty i samorządowe województwa, których liczba zmniejszyła się z 49 do 16. 
W związku z reformą zmieniono wiele ustaw. Bardzo ważnym aktem prawnym reformy ustrojowej była ustawa z 29 grudnia 1998 r. o zmianie niektórych ustaw w związku z wdrożeniem reformy ustrojowej państwa (Dz.U. Nr 162, poz. 1126). Mimo, że weszła w życie dopiero 1 stycznia 1999 r. ma znaczenie dla ustaw samorządowych., przede wszystkim dlatego, że zmienia dotychczasową ustawę o samorządzie terytorialnym z 8 marca 1990 r., jednocześnie nadając jej nowy tytuł: ustawa o samorządzie gminnym. Wśród innych zmian, jako najważniejsze można wskazać zmiany dokonane ustawami z 18 grudnia 1998 r.. Zmieniono wtedy ustawę z 7 października 1992 r. o regionalnych izbach obrachunkowych (Dz.U. z roku 1992, Nr 85, poz. 428, zmiana: Dz.U. z roku 1998, Nr 160, poz. 1062) i ustawę z 12 października 1994 r. o samorządowych kolegiach odwoławczych (Dz. U. Nr 122, poz. 593, zmiana: Dz.U. z roku 1998, nr 162, poz. 1124) Działem VI ustawy z 26 listopada 1998 r. o finansach publicznych (Dz.U. Nr 155, poz. 1014) uchylono prawo budżetowe z 1991 r. oraz wprowadzono odrębne postanowienia dotyczące budżetów jednostek samorządu terytorialnego.

W latach 1989-1998 nastąpiły liczne przekształcenia ustawowe które miały wpływ na obecny kształt samorządu terytorialnego. W wyniku reform nastąpiły zmiany w podziale administracyjnym kraju oraz kompetencjach poszczególnych organów administracji państwowej, co sprawiło iż współczesny samorząd nie jest tym samym podmiotem działalności publicznej jakim był na początku lat dziewięćdziesiątych.

\section{Bibliografia:}

Doganowski R. (2001) Ustrój i zadania samorządu terytorialnego, Wyższa Szkoła Zawodowa Administracji Publicznej, Sulechów.

Dolnicki B. (2001) Samorząd Terytorialny, Wolters Kluwer Polska Sp. Z o.o., Warszawa.

Gilowska Z. G. Gorzelak, B. Jałowiecki, K. Sobczak, (1998) Kierunki polityki regionalnej Polski. Studia Regionalne i Lokalne nr 24 (57), Uniwersytet Warszawski, Europejski Instytut Rozwoju Regionalnego i Lokalnego, Warszawa.

Gilowska Z.(1999) Powiat samorządowy - porażka czy wyzwanie?, Pomorski Przegląd Gospodarczy, 1,Gdańsk: Instytut Badań nad Gospodarką Rynkową

Gończar M. (1990) Samorząd wsi-historia i nowe możliwości, Fundacja Rozwoju Demokracji Lokalnej, Warszawa. 
Nawrot B. Poładecki J.(1999) Samorząd gminny $w$ Polsce. Doświadczenia $i$ perspektywy, Wydawnictwo Naukowe WNPiD UAM Poznań.

Obrębalski M. (red) (1991) Samorząd Terytorialny $w$ Polsce i Europie, Wydawnictwo AE Wrocław.

Pająk K.(2007) Samorząd terytorialny i jego wewnętrzna transformacja, Wydawnictwo Adam Marszałek, Toruń.

Słobodzian B. (2005) Wspótczesny system samorządu terytorialnego w Polsce, Wydawnictwo Adam Marszałek, Torun.

Tarno J.P. (red.) Samorzą terytorialny $w$ Polsce, Warszawa 2004.

Ustawa z dnia 10 grudnia 1993 r. o finansowaniu gmin, Dz. U. 1990, nr 129, poz. 600.

Ustawa z dnia 10 maja $1990 \mathrm{r}$. przepisy wprowadzające ustawę

o samorządzie terytorialnym i ustawę o pracownikach samorządowych, Dz. U. 1990, nr 32, poz. 191.

Ustawa z dnia 11 października 1991 r. o referendum gminnym, Dz. U. 1990. nr 110, poz. 47.

Ustawa z dnia 14 grudnia r. o dochodach gmin i zasadach ich subwencjonowania, Dz. U. 1990, nr 89, poz. 518.

Ustawa z dnia 17 maja 1990 r. o podziale zadań i kompetencji określonych w ustawach szczególnych pomiędzy organami gminy

a organami administracji rządowej oraz o zmianie niektórych ustaw, Dz. U. 1990, nr 34, poz. 198.

Ustawa z dnia 22 marca 1990 r. o pracownikach samorządowych, Dz. U. 1990, nr9o, poz. 124.

Ustawa z dnia 22 marca $1990 \mathrm{r}$. o terenowych organach rządowej administracji ogólnej Dz. U. 1990, nr 21, poz. 123.

Ustawa z dnia 24 maja 1990 o zmianie ustawy- kodeks postępowania administracyjnego Dz. U. 1990, nr 34, poz. 201.

Ustawa z dnia 8 marca 1990 r. o zmianie Konstytucji Rzeczypospolitej Polskiej, Dz. U. 1990 nr 16 poz. 94.

Wykrętowicz S. (red.) (2008) Samorząd w Polsce. Istota, formy, zadania, Wydawnictwo Wyższej Szkoły Bankowej, Poznań.

Wytrążek W. (2009) Samorząd terytorialny $w$ XX wieku $w$ Polsce, Wydawnictwo KUL, Lublin. 


\section{SUMMARY}

In the present article focuses on showing the transformation of local government in Poland after 1989. The writing discussed the issues related to the evolution of local government on the ground in the context of the changing political and social reality. Shown are the determinants of the transformation of local government, were also presented new legal conditions and their impact on the evolution of the local administration. Particular attention was paid to the reform of the administration in 1998 and its impact on the shape of the current administration.

\section{NOTA O AUTORCE}

Tecław Dominika (tecawd@gazeta.pl) - Uniwersytet im. Adama Mickiewicza w Poznaniu 2011 r. Doktorantka na Wydziale Nauk Politycznych i Dziennikarstwa na Uniwersytecie im. Adama Mickiewicza w Poznaniu. Interesuję się problematyka prasy lokalnej oraz samorządów terytorialnych. 